\title{
Teaching Poems: Exploring Life Skills
}

\section{Sarita Dewan}

"Poems offer a rich, varied repertoire and are a source of much enjoyment for teacher and learner alike." (Joanne Collie \& Stephen Slater, 1997)

As a high school teacher, I have always found teaching poems a source of developing language skills and different aspects too, including grammar, vocabulary and even communicative functions. Further, I have a feeling that teaching poems helps to develop creative, critical and analytical skills of students at this level.

Reading a poem is not to try to solve or explain what is written; rather it should be a process of demystification so that the students enjoy reading as well as are encouraged to write their own poems. I have often found the expressions of teenagers in the form of poems their frustrations, emotions, empathy and inner feelings - to be one way of sharing unspoken words.

This lesson takes an example of a poem from a $10^{\text {th }}$ grade class and focuses on how a lesson on teaching poetry can be taught effectively to enhance creative, critical and analytical skills, and to create awareness of literary devices at secondary and post-secondary levels. The lesson incorporates activities and possible strategies to boost higher levels (analysis, evaluation and creation) of thinking rather than "over emphasizing the language teaching aspects" (Ur, 1996).

Proficiency Level: Intermediate

Age Group: 14-18 years (secondary and post-secondary level in Nepal)

Class Time: $90-100$ minutes

\section{Objectives:}

The activities presented below seek to 1) elicit preliminary ideas on the poem from students, 2) guess the mood (feeling) of the poet, 3) get the exposure of the contextual use of vocabulary, 4) learn the use of literary devices, 5) motivate students to interpret the poem on their level using critical and creative thinking, and 6) motivate students to write poems of their own.

Resources: DVD clips, You-tube clips, worksheets, posters, realia, audio, songs, strips of poems, word cards, and pictures.

(The poem: "I Wandered Lonely as a Cloud" by William Wordsworth: CDC class 10) 


\section{Procedure}

\section{Pre-reading (10 minutes)}

The warm-up activity is to familiarize students with the topic and content of the poem. It further creates curiosity and motivation in students. The teacher starts with a discussion based on the theme of the poem and the poet's life. Then, the teacher shows the pictures of daffodils because they are not common in Nepal. Play the audio/ recitation of the poem. (https:// $\mathrm{w}$ w w. y o u t u b e.co m / watch?v=OnqCvDplPeA

Discuss the 'lazy time' of students. (How they feel, what they usually do and so on.)

\section{While reading activity (50 minutes)}

This phase include rearranging the poems in strips, and dealing with vocabularies, new structures and literary devices. It further comprises the activities to enhance critical and analytical skills.

\section{Rearranging the poem in strips (10 minutes)}

For this activity teacher needs to prepare earlier:

- Type the poem.

- Make copies according to the number of groups required.

- Cut each line of the poem in strips (There will be 24 strips in I Wandered Lonely as a Cloud: CDC class X).
In class:

- The strips are given to each group, and the students rearrange the poem in order.

- They compare how they have arranged the given strips with the poem in the textbook.

- The students share their experience of performing the assigned task.

- The teacher writes the experience of the students on the board.

If the poem is longer it can be reduced to stanzas. The activity motivates students to read the poem. Well-prepared reading activities can help to create momentum among students, hence silent or reading aloud must be carried out with purpose. Though reading aloud is less clear and difficult to understand, it can motivate less proficient learners. The teacher can read aloud to the class the first time.

II. Dealing with words and new structures (10 minutes)

Students get the exposure of vocabulary by choosing best definitions for the words, finding synonyms and antonyms or guessing the meaning. These activities help students understand the content and create a real impact, so that they are able to infer the meaning of the poem. 
Further, students analyse the words, choice of words and phrases used in the poem. The students need to be helped with unfamiliar words, phrases and 'unusual' syntactic features.

III. Literary elements and critical appreciation (15 minutes)

Discussion on the literary elements is necessary for deeper appreciation of the poem. In the poem "I Wandered Lonely as a Cloud," students will be exposed to literary devices like personification, metaphor, simile, the rhyming pattern of $\mathrm{ABABCC}$, and the rhyming couplet in the last two lines of each stanza. The teacher has greater roles to describe and practise those features. Then, the teacher generates discussion to critically analyze the theme based on the culture, historical context, environment, message, and other aspects of the poem, particularly at post-secondary level.

\section{Critical and analytical thinking (15 minutes)}

The teacher creates interaction among students with open-ended questions for comprehension and a quick summary of the poem, preferably in students' own words. $\mathrm{He} /$ she asks them to speak out in favor of or against ideas generated by the poem (enhancing debate): nature is the source of happiness, for instance. It will encourage students to use critical thinking or analytical skills. They can compare and contrast stanzas with reference to the content, theme, language, use of vocabulary, rhythm, rhyme, character, and so on. For developing their analytical thinking, let the students appreciate the poem through group discussion and then present to the whole class. They can even compare it with other poems they have learnt before. Students can also give their feedback on each other's presentations.

\section{Post-read activities (15 minutes)}

The teacher makes them recite the poem in rhythm together with him/ her. Students can perform role play, mime or simulation later. They can act as the poet, cloud and daffodils, and again recite the poem in the class. Converting the poem into illustrations is another interesting activity. The students can draw pictures imagining how beautiful golden daffodils would look to the poet.

\section{Class/home assignment (20 minutes)}

The teacher inspires students to write short and simple poems of their own in groups, pairs and at an individual level. Review, edit and let them recite to the whole group. Encourage their work to be published in the class or wall magazine, school magazine, blogs created by students, daily newspapers, and online magazines.

\section{Additional information}

The above-mentioned activities are based on my own experience of previously working as a teacher and the 
faculty head of Little Angels' School, Lalitpur, and presentations I made in some NELTA branches across the country.

\section{References}

Collie, J. \& Slater, S. (2009). Literature in the Language Classroom: A resource book of ideas and activities. Cambridge: Cambridge University Press.

Curriculum Development Centre. (2017). English textbook X. Curriculum Development Centre: Sanothimi, Bhaktapur.

Ur, P. (1996). A Course in Language Teaching: Practice and Theory. Cambridge: Cambridge University Press

\section{Contributor}

Sarita Dewan works for NELTA in the capacity of training coordinator. Ms. Dewan is the former head of the English department in Little Angels' School, Lalitpur. Ms. Dewan is also of member of Asian Teachers' Creative Writing Group. She has presented papers at national and international forums.

\section{Appendix 1}

\section{Types of poem}

1. Shape poem: It is a poem that takes on the shape of the thing you're writing, e.g. to write a poem about a flower, draw an outline of a flower and write inside the outline. It's a simple way of creativity. Just pick and draw any object and write about it inside the diagram.
2. 5 Senses poetry: It is written using the five senses (see, hear, smell, feel and taste).

3. Acrostic poetry: It is a form of poetry where a word is chosen and written vertically; first letters of each line forms a word or a line.

4. Color poetry: It is formed using colours relating to different events and characters. (effective for metaphor/ simile)

5. Alphabet poetry: Each line begins with the letters of alphabet.

6. Opposite words poetry: They can be written using opposite words in a line. For example; I am shy, you are friendly, You like cricket, I like football.

7. Cinquain poetry: It consists of five lines, with two syllables in the first and last line, four in the second, six in the third, and eight in the fourth line. Cinquains do not need to rhyme,

8. Limerick poetry: A limerick also has five lines. The last words of lines one, two and five rhyme. Similarly, the last words of lines three and four rhyme. A limerick has to have a pattern of stressed and unstressed syllables.

9. Free Verse poetry: A Free Verse Poem does not follow any rules. The creation is completely in the hands of the poet. The use of literary devices like metaphor, simile, rhyming, syllable count, punctuation, number of lines, number of stanzas, and line formation can be done in order to convey the idea. 
10. Rhyming Couplets: It consists of two lines of verse which rhyme and form a part of a poem.

11. Autobiographical poetry: It is written about oneself in a poetry form.

12. Haiku: It is a poem composed of three lines, and does not rhyme. The first line has five syllables, the second line has seven and the third and last line has another five. Traditionally, there is a seasonal reference included in the poem.

13. Alliteration poetry: It is poetry that has repetition of consonant sounds in words in the lines, e.g. Betty Butter, bought some butter, But the butter was bitter....

14. Creative copying: Students copy a poem changing the topic, theme or words in it. It is an interesting activity, but the students have to be made aware of plagiarism.

\section{Appendix 2}

\section{Wandered Lonely as a Cloud}

I wandered lonely as a cloud

That floats on high o'er vales and hills,

When all at once I saw a crowd,

A host, of golden daffodils;

Beside the lake, beneath the trees,

Fluttering and dancing in the breeze.
Continuous as the stars that shine

And twinkle on the milky way,

They stretched in never-ending line

Along the margin of a bay:

Ten thousand saw I at a glance,

Tossing their heads in sprightly dance.

The waves beside them danced; but they

Out-did the sparkling waves in glee:

A poet could not but be gay,

In such a jocund company:

I gazed - and gazed - but little thought

What wealth the show to me had brought:

For oft, when on my couch I lie

In vacant or in pensive mood,

They flash upon that inward eye

Which is the bliss of solitude;

And then my heart with pleasure fills,

And dances with the daffodils.

William Wordsworth 